INTERNATIONAL JOURN AL OF RESEARCHES IN BIOSCIENCES, AGRICULTURE AND TECHNOLOGY (c) VISHWASHANTI MULTIPURPOSE SOCIETY (G lobal Peace Multipurpose Society) R. No. MH-659/13 (N) www.vmsindia.org

\title{
MITOTIC INDEX (MI) AND PHASE INDEX (PI) IN ALLIUM SATIVUM LINN. (VARIETY AGRIFOUND WHITE AND YAMUNA SAFED)
}

\author{
Sukeshini Deogade ${ }^{1}$ and P. N. Nasare ${ }^{2}$ \\ iDe partment Of Botany, Hislop College, Civil Line, Nagpur (M.S.) India. \\ ${ }^{2}$ De partment Of Botany, Nilkanthrao Shinde Science And Art's College, Bhadrawati Dist.- Chandrapur (M.S.) India. \\ sukeshinishahare@gmail.com
}

\begin{abstract}
:
Mitotic cell division was observed in root tips of varieties of Allium sativum L. i,e Agrifound white and Yamuna safed fixed in Carnoy's fixative (Glacial acetic acid : absolute alcohol, 1:3) at different intervals of time, i.e 8.008.30am, 8.30-9.00am, 9.00-9.30am, 9.30-10.00am, 10.00-10.30am, 10.30-11.00am. The number of semipermanent squash preparations were observed for the study of mitotic activity. For each time 20 slides were observed to scored prophase, metaphase, anaphase and telophase. In the varieties of Agrifound white, maximum metaphases $(9.10 \%)$ and anaphases $(5.15 \%)$ observed at the time 9.00-9.30am, and in Yamun safed, maximum metaphases $(10.10 \%)$ and anaphases $(7.30 \%)$ observed at the time 9.30-10.00am respectively. The purpose of present study is to know the mitotic index and phase index in Allium sativum L. varie ties (Agrifound white and Yamuna safed) for proper study of the chromosomes for karyotype analysis.
\end{abstract}

Keywords: Allum sativumL., Mitotic cell division, Mitotic index and Phase index.

\section{Introduction}

The genus Allium comprises about 700 species. Several of them are important vegetables, spices and medicinal plants.

Allium satioum L. (garlic) a member of the Liliaceae family and a popular condiment is cultivated all over the world. The chromosome number of Allium species, is reported as $2 \mathrm{n}=16$ (Levan, 1935, Mensinkal, 1939) and $2 n=18$ in two varieties of garlic (Sharma and Bal, 1959). Intraspecific variations in the size and type of chromosomes, positions of the secondary constrictions and positions and numbers of the heterochromatic bands occur frequently in most of plant species.

Aerial stems of Allium sativum L. are to $+1 \mathrm{~m}$ tall, erect, simple, herbaceous, green, glabrous, te rete mostly hollow. Bulb of many bulblets, with a papery coating and fibrous roots. Bulble with at least one flat side. Leaves present in the lower $1 / / 3$ to $1 / 2$ of the plant. Leaves flat or very slight folded, to $+/-30 \mathrm{~cm}$ long, $7-10 \mathrm{~mm}$ broad, glabrous, often glaucous, with a prominent midrib, sheathing. The ligule rounded ( "U"shaped), the free portion 1-2 $\mathrm{mm}$ tall (long). Inflorescence dense capitate cluster of bulblets te rminating the stem. Inflorescence covered in a papery spathe. Spathe with a long tip, splitting on one side at anthesis. Flowers mostly or entirely replaced by bulble ts. Bulblets glabrous, whitish (more commonly) with a reddish tinge. If produced, the small flowers are greenish, whitish, or pinkish and tubular with acute lobes. Bulbs of Agrifound White (G-41) are compact, silvery and white with creamy flesh. A bigge relongated clove with 20-25 in number and diameter of bulb is $3.5-4.5 \mathrm{~cm}$. Recommended for Maharashtra and Madhya Pradesh. Chromosome number is $2 n=18$. The material was procured from Dr. Punjabrao Deshmukh Krishi Vidyapee th, Akola. (M.S.).

Bulbs of Yamuna Safed are creamy white and bigger sized with 4.5-6 cm in diameter. Number of cloves/ bulbs is 15-16. Recommended for Madhya Pradesh, Maharashtra, Haryana, Gujarat, Punjab, Rajasthan, Uttar Pradesh and Chhattisgarh. Chromosome number is $2 \mathrm{n}=18$. The material was procured from National Horticulture Research Development and Foundation, Nashik (M.S.).

Several investigators have worked on mitotic cell divisions in different plants Viz. Lens culinaris Medik (Yasar Kiran and Ahmed Sahni, 2006), Capsicum annum L.(Yadav and Yadav, 2010), Ocimum sanctum L. (Nasare and Choudhary, 2010), Triticum aestivum L. (Sanjaykumar et al,2010), Hibiscus rosa-sinensis (Ozmen Ali, 2010), Treculia Africana Decne. (Osiji et al., 2010), Saccharum spp. (Shrivastava and Jain, 2011), and Phaseolus vulgaris L. and Raphanus sativus L. (Elena et.al, 2011), Allium cepa L. (Paul et al., 2013), Vigna unguiculata Linn. (Amirthalingam et al., 2013), Allium cepa L. ( Udo et al., 2014), Allium cepa L. (Pankaj et al., 2014).

The present study was designed to study the mitotic activity and phase index in the root meristems of Allium sativum L. to find out the maximum mitotic activity at specific time for each variety of Allium. 


\section{Materials and Methods}

Healthy cloves of Allium sativum L. varieties Agrifound white and Yamuna safed were selected and kept for germination on the jars filled with water. After 4 days, root tips were harvested with the help of blade that had attain the length of $1-1.5 \mathrm{~cm}$ and fixed in Carnoy's fixative $(1: 3$, glacial acetic acid: absolute alcohol, $\mathrm{V} / \mathrm{V})$ for 24 hours in refrige rator. Fixed root tips we re washed with distilled water and macerated in $1 \mathrm{~N} \mathrm{HCl}$ for $10-15 \mathrm{~min}$. at $60^{\circ} \mathrm{C}$ in hot air oven. Mace rated root tips were transfer to $2 \%$ acetocarmine stain for $20 \mathrm{~min}$. for proper staining. Stained root tips were the n squashed in stain and cover glass (cover slip) was sealed with paraffin wax. The chromosome spreads we re then observed microscopically. The cells we re scored for the diffe rent cell division stages, number of total dividing cells, number of prophases, number of metaphases, number of anaphases and number of telophases were scored. During mitotic cycles of the cell division at different intervals of time, data was prepared to calculate mitotic index (MI) and phases indices (PI) by following formulae (Bhatta and Sakya, 2008).

The different phases of mitosis were counted to calculate the mitotic index (MI) and phase indices, as following:

Mitotic Index $=\mathrm{TDC} \times 100 / \mathrm{TC}$

$\mathrm{PI} \%=$ prophase cells $\times 100 / \mathrm{TDC}$

$\mathrm{MI} \%=$ metaphase cells $\times 100 / \mathrm{TDC}$

$\mathrm{AI} \%=$ anaphase cells $\times 100 / \mathrm{TDC}$

$\mathrm{TC} \%=$ telophase cells $\times 100 / \mathrm{TDC}$, whe re

$\mathrm{TC}=$ total cells (dividing and non-dividing), and TDC $=$ total dividing cells.

\section{Result and Discussion}

In the present study, mitotic activity and mitotic chromosomes were studied and the data for the same is presented in the table 1 and 2 .

At the times around the clock, the re was cell division (Table 1). The rate of division varied widely between the time periods of 8.00 am to $11.00 \mathrm{am}$. The percentage of dividing cells is higher in the time $9.00 \mathrm{am}$ to $10.00 \mathrm{am}$ than others. At about 8.00 am to 8.30 am a high percentage of prophase cells were recorded.

The cells that enter mitotic process start from the prophase stage as corroborated by the rise in the number of cells at this stage. Metaphase increased after prophase and continued mostly be tween $9.00 \mathrm{am}$ to $10.00 \mathrm{am}$.

From the table number 1 there were always cells at the various stages of the mitotic division. The observation of the highest number of metaphase cells at the period between 9.00 am to $9.30 \mathrm{am}$. The rise in the number of cells in anaphase was after the rise in the number of those at metaphase. The highest number of anaphase cells at the period between 9.00 am to $9.30 \mathrm{am}$.

Hence there were always cells at the various stages of the mitotic division. The obse rvation of the highest number of metaphase cells at the period between $9.30 \mathrm{am}$ to $10.00 \mathrm{am}$. The number of cells at the period at anaphase started to rise at about $9.30 \mathrm{am}$ to $10.00 \mathrm{am}$. The rise in the number of cells in anaphase was after the rise in the number of those at metaphase. The highest number of anaphase cells at the period between 9.30 am to 10.00 am.

For this study, different stages of mitosis (Prophase, metaphase, anaphase, telophase) were counted to calculate mitotic index and phase indices.

From the table number 1 , it was observed that mitotic index was found maximum $(26.41 \pm 0.18)$ at the time $9.00-9.30$ am and phase index was found maximum (421.63) at the time 10.30 $11.00 \mathrm{am}$. While mitotic index was found minimum (23.72 \pm 0.14$)$ at $10.30-11.00$ am and phase index was found minimum (378.68) at the time $9.00-9.30 \mathrm{am}$.

From the table number 2, it was observed that mitotic index was found maximum $(27.76 \pm 0.19)$ at the time $9.30-10.00$ am and phase index was found maximum (387.82) at the time $10.00-10.30$ am. While mitotic index was found minimum $(25.79 \pm 0.19)$ at $10.00-10.30$ am and phase index was found minimum (361.48) at the time $9.00-9.30 \mathrm{am}$.

The data of mitotic index and phase index is also presented in following bar diagrams.

Several cytologist were studied the mitotic index and phase index in many plants viz.,Foeniculum vulgare (Jahagirdar, 1975), Coriandrum satiwum (Gaikwad, 1975), Carcum copticum (Khanolkar, 1977), Solanum nigrum (Kothekar, 1978), Cajanus cajan (Chary and Bhalla, 1987), Oryza sativa s(Ramesh, 1987), Vicia faba (Abraham and Nayar, 1989), Medicago sativa (Singh et al., 1990), Trigonella foenum-graecum (Devi, 1990), Pearl millet (Bansikar and Srivastava, 1992), Linum usitatissimum (Karpate, 1995), Cyamopsis tetragonoloba (Kanaklata, 1995), Lathyrus sativus (Girhe, 1999), Brassica napus (Lange, 2000), Lens culinary Medik (Yasar and Ahmet, 2006), Hordeum vulgare L. (2007), Triticum aestivum L. (Sanjay kumar et al, 2010), Capsicum annum (Yadav and Yadav, 2010), 
Ocimum sanctum L. (Nasare and Choudhary, 2010), Hibiscus rosa-sinensis (Ozmen Ali, 2010), Treculia Africana Decne. (Osiji et al., 2010), Saccharum spp. (Shrivastava and Jain, 2011), Phaseolus vulgaris L. and Raphanus sativus L.
(Ele na et.al, 2011), Allium cepa L. (Paul et al., 2013), Vigna unguiculata Linn. (Amirthalingam et al., 2013), Allium cepa L. (Udo et al., 2014) and Allium cepa L. (Pankaj et al., 2014).

Table 1: Shows Mitotic index (MI) and Phase Index (PI) in root tips cells of Allium sativum (Agrifound white) Linn.

\begin{tabular}{|l|l|l|l|l|l|l|l|l|}
\hline $\begin{array}{l}\text { Time } \\
\text { Intervals }\end{array}$ & TC & TDC & $\begin{array}{l}\text { Prophase } \\
\text { index }\end{array}$ & $\begin{array}{l}\text { Metaphase } \\
\text { Index }\end{array}$ & $\begin{array}{l}\text { Anaphase } \\
\text { Index }\end{array}$ & $\begin{array}{l}\text { Telophase } \\
\text { Index }\end{array}$ & $\begin{array}{l}\text { Mitotic } \\
\text { Index } \pm \text { SE }\end{array}$ & $\begin{array}{l}\text { Phase } \\
\text { Index }\end{array}$ \\
\hline $8.00-8.30 \mathrm{am}$ & 1683 & 413 & 11.17 & 6.18 & 4.63 & 2.73 & $24.54 \pm 0.20$ & 407.50 \\
\hline $8.30-9.00 \mathrm{am}$ & 1667 & 440 & 11.82 & 8.33 & 4.08 & 2.10 & $26.39 \pm 0.19$ & 378.86 \\
\hline $9.00-9.30 \mathrm{am}$ & 1670 & 441 & 10.54 & 9.10 & 5.15 & 2.40 & $26.41 \pm 0.17$ & 378.68 \\
\hline $9.30-10.00 \mathrm{am}$ & 1628 & 407 & 7.31 & 8.85 & 5.10 & 3.75 & $25.00 \pm 0.13$ & 400 \\
\hline $10.00-10.30 \mathrm{am}$ & 1691 & 413 & 6.86 & 8.28 & 4.90 & 4.02 & $24.42 \pm 0.17$ & 409.44 \\
\hline $10.30-11.00 \mathrm{am}$ & 1657 & 393 & 6.46 & 7.97 & 5.07 & 4.47 & $23.72 \pm 0.14$ & 421.63 \\
\hline
\end{tabular}

$\mathrm{SE}=$ Standard Error $( \pm)$

Table 2: Shows Mitotic index (MI) and Phase Index (PI) in root tips cells of Allium sativum (Yamuna safed) Linn.

\begin{tabular}{|l|l|l|l|l|l|l|l|l|}
\hline Time Intervals & TC & TDC & $\begin{array}{l}\text { Prophase } \\
\text { index }\end{array}$ & $\begin{array}{l}\text { Metaphase } \\
\text { Index }\end{array}$ & $\begin{array}{l}\text { Anaphase } \\
\text { Index }\end{array}$ & $\begin{array}{l}\text { Telophase } \\
\text { Index }\end{array}$ & $\begin{array}{l}\text { Mitotic } \\
\text { Index } \pm \text { SE }\end{array}$ & $\begin{array}{l}\text { Phase } \\
\text { Index }\end{array}$ \\
\hline $8.00-8.30 \mathrm{am}$ & 1601 & 418 & 10.31 & 8.81 & 4.43 & 2.44 & $26.11 \pm 0.47$ & 383.01 \\
\hline $8.30-9.00 \mathrm{am}$ & 1571 & 422 & 11.84 & 8.98 & 4.39 & 1.97 & $26.86 \pm 0.26$ & 372.27 \\
\hline $9.00-9.30 \mathrm{am}$ & 1511 & 418 & 10.52 & 9.07 & 4.90 & 2.45 & $27.66 \pm 0.08$ & 361.48 \\
\hline $9.30-10.00 \mathrm{am}$ & 1567 & 435 & 7.85 & 10.15 & 7.21 & 2.62 & $27.76 \pm 0.19$ & 360.23 \\
\hline $10.00-10.30 \mathrm{am}$ & 1528 & 394 & 7.73 & 8.44 & 5.56 & 4.25 & $25.79 \pm 0.19$ & 387.82 \\
\hline $10.30-11.00 \mathrm{am}$ & 1471 & 405 & 8.84 & 8.91 & 5.03 & 4.69 & $27.53 \pm 0.18$ & 363.21 \\
\hline
\end{tabular}

$\mathrm{SE}=$ Standard Error $( \pm)$

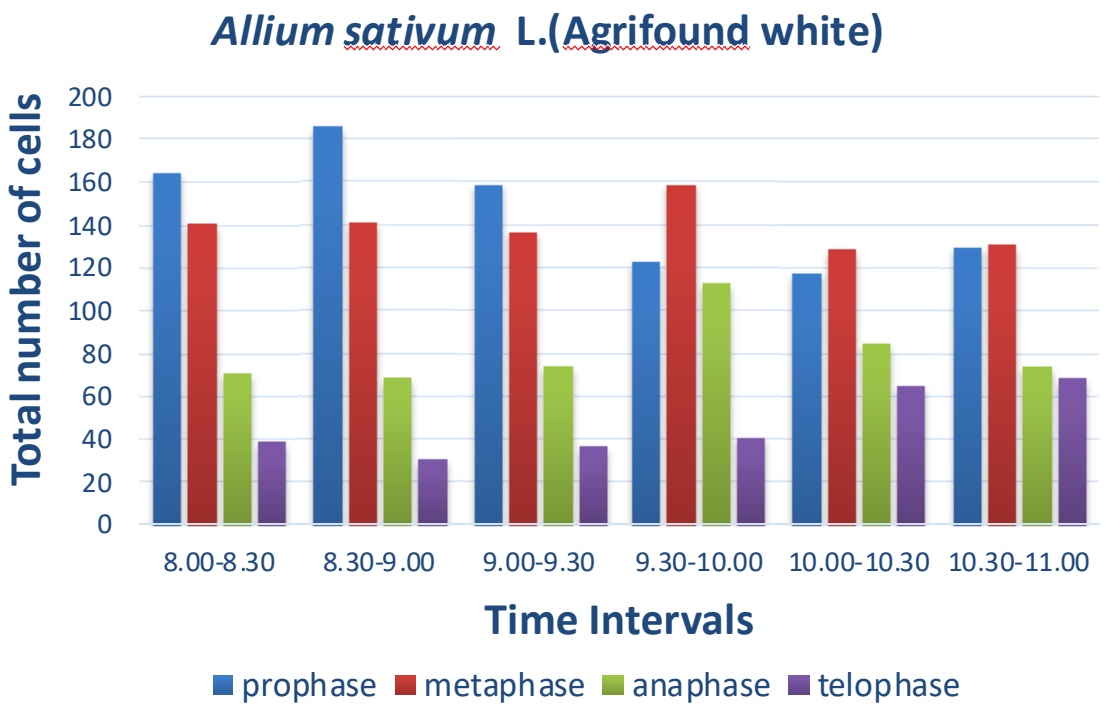




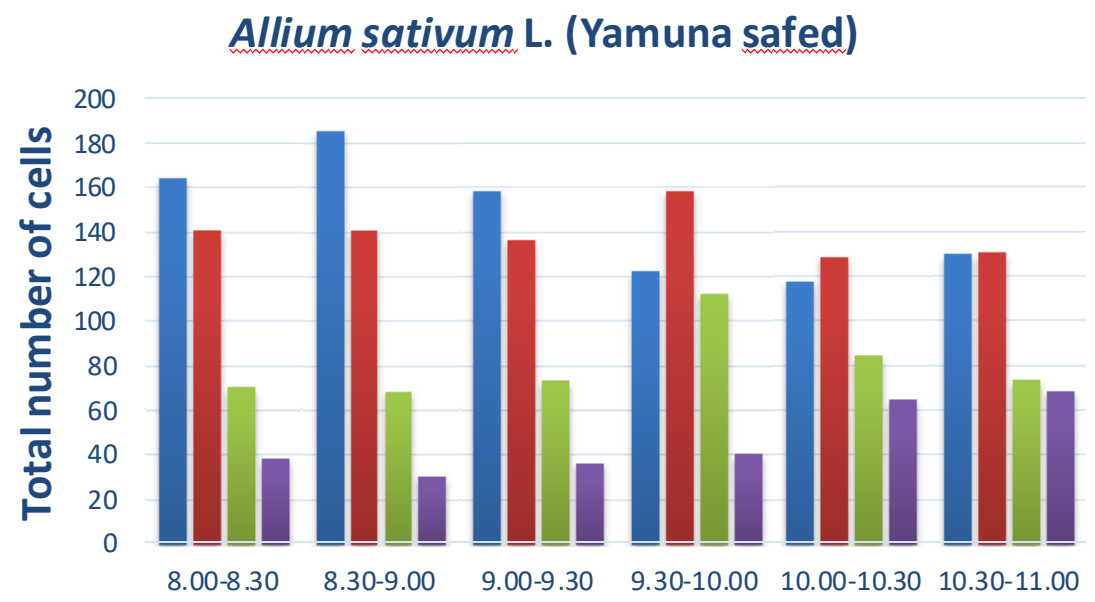

Time Intervals

aprophase $\square$ metaphase $\square$ anaphase $\square$ telophase

\section{Conclusion}

The authors concludes the present investigation reveals that for karyotype analys is of Allium species, the pre-requisite study of mitotic and phase index is essential. Information and data presented in this work is expected to be valuable for further chromosomal study.

\section{Acknowledgement}

Author's thanks to Dr. Mousmi Bhowl (Head) and Dr. K. J. Cherian (Ex-Head) Department of Botany, Hislop College, Civil Lines, Nagpur for providing all possible resource materials and facilities available in the department whenever required without any hesitation. Thanks to Dr. Dip ti Christian, Principal, Hislop colle ge, Nagpur for her timely help and kind cooperation. We acknowledge our gratitude to Dr. L. S. Ladke, Principal, Nilkanthrao Shinde Science And Art's College, Bhadrawati and Mr. N.Y. Shinde (ExMLA), Secretory, Bhadrawati Shikshan Sanstha, Bhadrawati for their valuable guidance kind cooperation.

\section{References}

[1] Adegbite A. E. and Sanyaolu E. B. (2009): Cytotoxicity te sting of aqueous

extract of bitter leaf (Vernonia amyglalina Del.) using the Allium cepa chromosome aberration assay. Scientific research and Essay Vol. 4(11), pp. 1311-1314.

[2] Adegbite A. E., Ayodele M. S., Odunbaku K. R. and Idehen E. O. (2009): Mutagenic effect of neem leaf extract used in traditional medicine on Allium cepa (L.). Scientific Research and Essays Vol. 4(11), pp. 1315-1321.
[3] Ali O. (2010): Cytotoxicity of Hibiscus rosasinensis flower extract. Caryologia Vol. 63, no. 2: 157-161.

[4] Amirthalingam T., Velusamy G. and Pandian R. (2013): Cadmium- induced changes in mitotic index and genotoxicity on Vigna unguiculata (Linn.) Walp. Journal of Environmental Chemistry and Ecotoxicology. Vol. 5(3), pp. 5762.

[5] Bansikar V. and Srivastava A. K. (1992): Mercury induced chromosomal inconstancy in Pearl millet. J. Cytol. Genet. 27: 79-90.

[6] Bhatta P. and Sakya S.R. (2008): Study of mitotic activity and chromosomal behavior in root meristem of Allium cepa L. treated with magnesium sulphate. Ecoprint, 15: 83-88.

[7] Chary H.S. and Bhalla J. K. (1987). Chromosomal abnormalities induced by gamma rays magnetic fields and EMS in Pigeon pea, Cajanus cajan (L. Milli sp). In Proc. "First All India Conference on Cytology and Genetics" Banglore, India. 41.

[81 Devi P. (1990): Cytological effects of chemical mutagen on Trigonella foenum-graecum L. J. Cytol. Ge net. 25, 117-119.

[9] Elena Truta, Maria-Magdalena Zamfirache and Zenoviaolteanu (2011): Caffeine induced ge notoxic effects in Phaseolus vulgaris L. and Raphanus sativus L. Botanical Serbica 35(1): 49-54.

[10] Gaikwad P. D. (1975): Cvtogene tic studies in Coriandrum sativum Linn.Ph.D. Thesis in Botany, Faculty of Science, RTM Nagpur Unive rsity, Nagpur, India.

[11] Girhe S. (1999): Mutational Studies in Lathyrus sativus L. Ph.D. 
Thesis in Botany, Faculty of Science, RTM Nagpur University, Nagpur,

India.

[12] Heiner R. E. (1971): Alternations in the nuclear cvcle, mitotic index and chromosomes of Vicia as affected by diethyl sulphate. Mut. Res. 12: 249-254.

[13] Jahagirdar H. A. (1975): Cytogene tic stud ies in Foeniculum vulgare Mill, Ph.D. Thesis in Botany, Faculty of Science, RTM Nagpur University, Nagpur, India.

[14] Kanaklata (1995): Mutational studies in Cyamopsis te tragonoloba Taub. Ph.D. Thes is in Botany, Faculty of Science, RTM Nagpur university, Nagpur, India.

[15] Karapate R. R. (1995): Mutational studies in Linum usitatisissum L. Ph.D. Thesis in Botany, Faculty of Science, RTM Nagpur University, Nagpur, India.

[16] Khanolkar S. M. (1977): Cytogene tic studies in Carcum copticum. Ph.D. Thesis in Botany, Faculty of Science, RTM Nagpur University, Nagpur, India.

[17] Kothekar V. S. (1978): Mutational studies in Solanum nigrum L. Ph. D. Thesis in Botany, Faculty of Science, RTM Nagpur University, Nagpur, India.

[18] Land ge S. P. (2000): Induced mutations in Brassica napus (L.) C.V. Westar. Ph.D. Thes is in Botany, Faculty of Science, RTM Nagpur University, Nagpur, India.

[19] Nasare P. N. and Choudhary A. D. (2000): Effect of physical and chemical mutagens on mitotic activity in root tips of Ocimum sanctum Linn. Int. J. Mendel, Vol. 27: 53-55.
[20] Osuii, Julian O. and Owei, Sweet D. Jnr. (2010). Mitotic index studies on Treculia A fricana Decne. In Nigeria. Australian Journal of Agricultural Engineering. 1(1): 25-28.

[211 Pankai P. P., Kumari N. and Priadarshini A. (2014): Evaluation of cytotoxic in Allium cepa L. root tips cells. International Journal of Pharmaceutical and Clinical Research. 6(1): 3639.

[221 Paul A., Nag S. and Sinha K. (2013): Cytological effects of Blitox on root mitosis of Allium cepa L. International Jou rnal of Scientific and Research Publications. Vol. 3 Is sue 5.

[23] Saniavkumar, Arva S. K., Rov B. K. and Singh A. (2011): The effects of 2,4dichlorophenoxy acetic acid and isoproturon herbicides on the mitotic activity of Wheat (Triticum aestivum L.) root tips. Turk J Biol. 34: 55-66.

[24] Srivastava S. and Jain R. (2011): In-situ monitoring of chromium cytotoxicity in Suge rcane J. Environ. Biol. 32: 759-763.

[25] Udo I. J., Akpan G. A., and Esenowo I. K. (2014): Cvtotoxic effects of (5) medicinal plants on mitosis in Allium cepa root tips. Current Research Journal of Biological Sciences. 6(2): 71-75.

[26] Yasar Kiran and Ahmet Sahin (2006): The effect of cadmium on seed germination, root development and mitotic of root tip cells of Lentic (Lens culinaris Medik). World Journal of Agricultural sciences 2 (2): 196-200.

[27] Yasemin E., Halil E. E. and Ali I. I. (2007): Gamma ray reduces mitotic index in embryonic roots of Hordeum vulgare L. Advances in Biological Research 1(1-2): 26-28. 